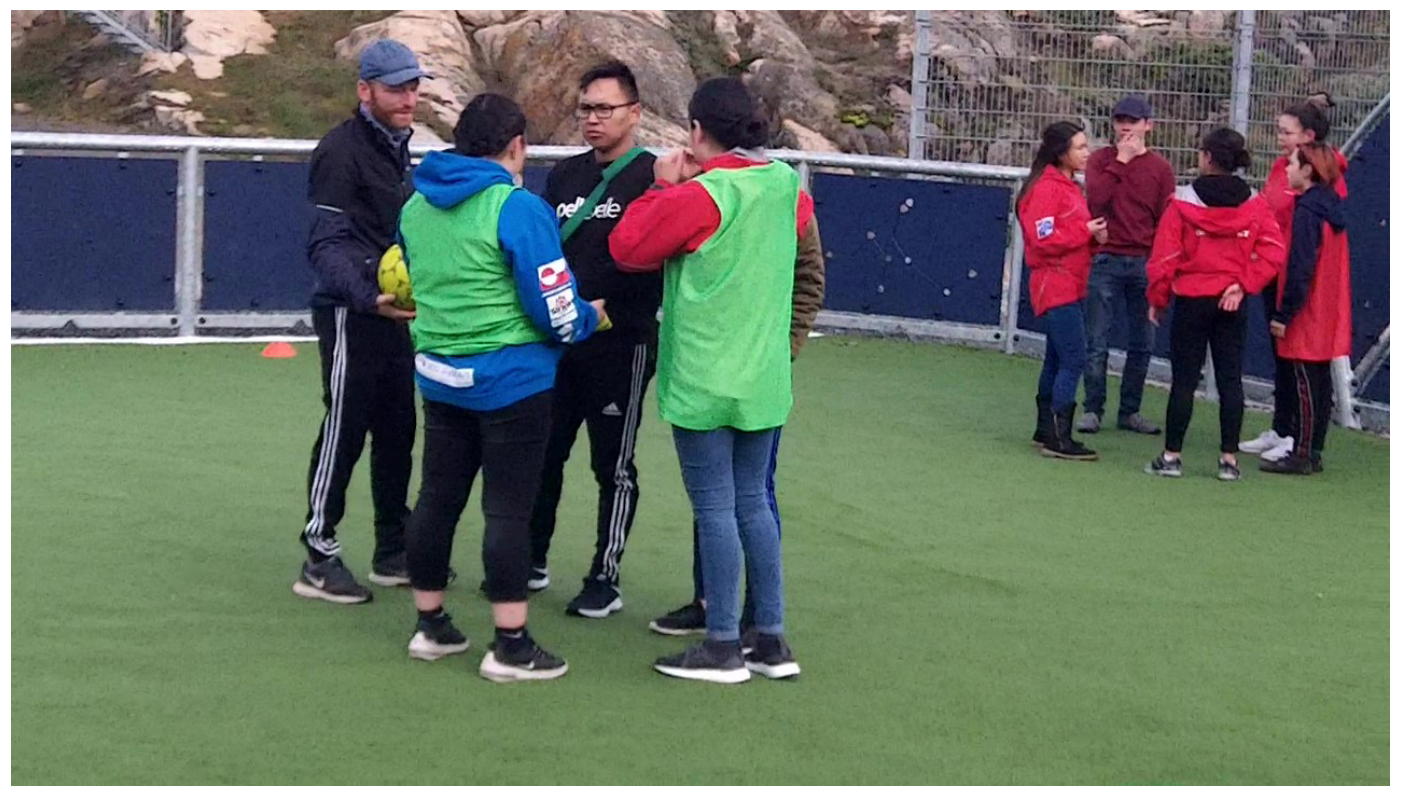

\title{
Etablering af et Professionelt LæringsFællesskab blandt idrætslærere på et grønlandsk gymnasium
}

\section{LARS ELBÆK** ${ }^{*}$, NICOLAI KORFIX NIELSEN*, KRISTIAN NORMANN} PEDERSEN* OG ANNE HOUMØLLER*

** Institut for Idræt og Biomekanik, Syddansk Universitet

${ }^{*}$ GUX Sisimiut, Gymnasiet i Sisimiut, Grønland

I gymnasieskolen opleves i idrætsundervisning, som i andre fag, kulturelle udfordringer med gymnasiefremmede elever. Nærværende artikel kobler sig til disse problematikker i det grønlandske gymnasium ved at analyserer og belyse idrætslærernes arbejde med at skabe en udviklende kultur i idrætslærergruppen, herunder udvikling af et Professionelt LæringsFællesskab (PLF) i en grønlandsk kontekst. 


$$
\begin{array}{r}
\text { LARS ELBÆK } \\
\text { Lektor, ph.d. } \\
\text { Institut for Idræt og Biomekanik, SDU } \\
\text { lelbaek@health.sdu.dk }
\end{array}
$$

NICOLAI KORFIX NIELSEN

Gymnasielærer

GUX Sisimiut

nini@kti.gl

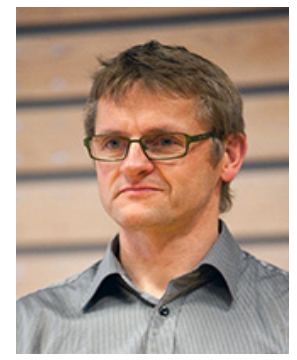

KRISTIAN NORMANN PEDERSEN

Gymnasielærer

GUX Sisimiut

kped@kti.gl

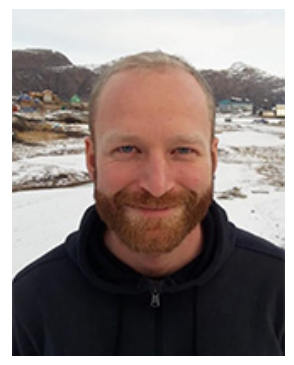

ANNE HOUMØLLER

Gymnasielærer

GUX Sisimiut

anho@kti.gl
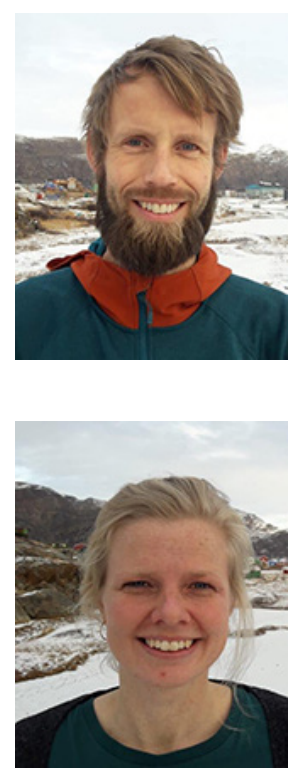

Hovedfokus i denne artikel omhandler lærernes evner og vilje til at samarbejde om til stadighed at udvikle deres og institutionens undervisning. Udvikling af PLF skete sideløbende med at, lærerne skabte et introducerende forløb i idrætsundervisning, der tager højde for de gymnasiefremmede elevers kulturelle udfordringer. I denne udfordring indgår blandt andet, at en del elever flytter på kollegier, og de fleste grønlandske elever oplever sproglige udfordringer ved overgangen til gymnasieskolen. Etablering af et PLF og den dertil knyttede udvikling af undervisningen udfoldede sig på gymnasieskolen i Sisimiut i Vestgrønland, hvor 1.G eleverne 
deltog i et intro-forløb til idræt, og 4 lærere deltog som medforskere. Metodisk er etableringen af PLF funderet i aktionsforskning (AF), der opererer mellem tænkning omkring og handling i praksis, og hvor praktikere (idrætslærere) og forskere samarbejder. Idrætslærerne udviklede praksis gennem et demokratisk samarbejde og med specialestuderende (og idrætslærer) som projektejer. Aktionsforskningen i gennemførte praksis forløb over faserne afklaring (kendskab til praksis), planlægning, aktion og refleksion (analyser). De fælles forskningsaktiviteter støttet af en forsker (konsulent), alias specialevejleder og førsteforfatter, udfoldedes i 9 arbejdsgruppemøder plus observationer af aktioner samt 8 post-aktion samtaler, og i efterfølgende 5 refleksions- og analysemøder. Efterfølgende er data fra mødejournaler, observationer og interview analyseret tematisk. Dette førte til udvikling af analysetræet med et meta-niveau, og temaer formidles blandt andet gennem 3 . persons procesfortællinger, byggende på "modifying realist tales".

Analyserne viser, at arbejdet med udvikling af en ny praksis førte til udvikling af et PLF (Professionelt LæringsFællesskab), at projektets rammer i form af kontekst, præmisser og processen havde afgørende indflydelse på de opnåede resultater, at projektejers ambitioner og vedholdenhed om elevinvolvering var nøglen til at sikre udvikling af undervisningskulturen, at handletvang i forhold til afprøvning (aktion) af konkret undervisning kan fremme beslutningstagen og derigennem medieres nye indsigter, og at praksis med selvpålagt udvikling fordrer åbenhed blandt lærerne, udfordrer rollerne og kan fremme relationerne i lærergruppen. Den i metaanalyserne efterfølgende dekonstruktion af aktionsforskningsaktiviteterne og samtidige tingsliggørelse af ny undervisningspraksis finder vi har været afgørende for den fælles forståelse af udvikling af et PLF.

Begrebet PLF omtales i forskningen under det engelske begreb "Professional learning communitites (Qvortrup, 2015). Turner, Christensen, Kackar-Cam, Fulmer, \& Trucano (2018) beskriver, at målet med PLF er at udvikle god undervisning gennem samarbejde i lærerteams. PLF-tilgangen bygger på at skabe en professionel lærerkultur, der ser udvikling som en integreret del af undervisningen (Vangrieken, Meredith, Packer, \& Kyndt, 2017). I forskningen er det imidlertid uklart, hvordan PLF'er udvikler sig til lærende fællesskaber, der udvikler god undervisning. Ifølge Turner et al. (2018) skyldes det begrænsede analyser af de ændringsmekanismer, der fører til velbegrundede forbedringer. Formålet i artiklen er derfor at:

Undersøge hvilke elementer der indgår i opbygningen af et professionelt læringsfællesskab mellem idrætslærere i forhold til at understøtte grønlandske gymnasieelevernes kulturelle udfordringer i idrætsundervisningen?

Sammenfattende fandt vi, at der gik mere end et år før de første skridt var taget i forhold til at etablere et PLF med et fælles repertoire. Dette ligger i tråd med Casey 
og Goodyear (2015), der fremhæver at udvikling af PLF'er er et langstrakt og krævende arbejde. Vi finder, det kræver vedholdenhed, åbenhed og løbende udvikling af de relationelle forhold at udvikle lærernes fortsatte læring gennem undervisningsudvikling i et Professionelt LæringsFællesskab.

Baggrunden for undersøgelsen er, at traditionen for videregående uddannelser i Grønland er ung, og det derfor primært er danske lærere, som arbejder og underviser på dansk i de grønlandske gymnasier og videregående uddannelser. Dette står i modsætning til grønlandske folkeskoler, hvor der primært undervises på grønlandsk af lærere med grønlandsk baggrund (Boolsen, 2015). Den sproglige udfordring skaber, sammen med en overvægt af 1.-generations elever i gymnasiet i Grønland, de såkaldte gymnasiefremmede elever, hvor forældrene ikke har en gymnasial uddannelse, udfordringer i undervisningen. Specielt i den grønlandske gymnasieskole, men også i den danske, er antallet af gymnasiefremmede elever steget de seneste år (Sano 2017; Murning \& Hutters, 2014).

Problemstillingen forstærkes af, at de fleste byer i Grønland er små og ikke har videregående skoler. De unge forlader derfor deres hjemby i en tidlig alder for at kunne fortsætte i skolesystemet, hvilket for nogle elever medfører et oplevet kulturchok (Boolsen, 2015). Det kan yderligere medføre følelser af hjemve, afsavn til familien, problemer med at finde ud af, hvad der foregår i de ny uddannelsesmæssige rammer, finde rollen som studerende, knytte venskaber til andre elever og samarbejde med hinanden (Boolsen, 2015). Ovennævnte sammen med den almindelige transitionsproblematik til gymnasiet (Ulriksen et al., 2009) skaber en dobbelt kulturel udfordring, som også afspejles i idrætsundervisningen.

Nærværende artikel kobler sig til denne problematik i det grønlandske gymnasium ved at undersøge etableringen af en idrætslærergruppe, der har fokus på udvikling og arbejde med (og måske løsning af) problemet.

Det har ikke tidligere været undersøgt, hvordan PLF'er udvikles i den grønlandske idrætsundervisning i gymnasieskolen, og det har ikke været muligt at finde andre studier, der undersøger udviklingen af PLF'er i en kulturelt udfordret idrætsundervisning som den grønlandske.

Vi indleder med at redegøre for PLF og det teoretiske grundlag fra praksisfællesskaber. Herefter redegøres for konteksten og de ministerielle præmisser for idrætsundervisning i Grønland. Dette er grundlag for at beskrive projektets metodiske afsæt i aktionsforskning. De konkrete aktiviteter anvendt i aktionerne og datagenereringsmetoder samt analysemetode, der er fundet relevante, legitime og brugt i forskningen, skitseres. Ud fra anvendte procesanalyser og de efterfølgende meta-refleksioner og -analyser beskrives temaer og elementer, der har bidraget til indsigter i udvikling af PLF. Fundene i udvikling af PLF diskuterer vi i forhold til 
praksisfællesskaber og ud fra andre undersøgelser af PLF'er samt ud fra videnskabsteoretiske ståsteder. Endelig kommer vi med anbefalinger til etablering af PLF'er blandt idrætslærere.

\section{UDVIKLING AF ET PROFESSIONELT LAERINGSFALLLESSKAB}

Hargreaves (2009) hævder, at en af forudsætningerne for udvikling af PLF'er er (på engelsk "Professional Learning Community" - PLC), at lærerne først rigtigt kan lære, når de kommer uden for eget klasseværelse og samarbejder med andre lærere, og det er et væsentligt princip bag PLF’er. I etablering af læringsfællesskaber er en del af opgaven i højere grad selv at søge og bruge viden frem for at deltage i traditionelle kurser (Vangrieken et al., 2017). Fokus i læringsfællesskaber er derfor; kollektiv læring, at lærerne må udfordre hinanden, dele viden, bruge viden og opsøge ny viden, såvel som deling af hinandens praksis, og herigennem give feedback på undervisning (Turner et al., 2018). Dette blandt andet med sigte på at styrke lærernes faglige dømmekraft og didaktiske praksis i forhold til elevernes læring (Qvortrup, 2015). Ud over teamorganiseringen som den ene forudsætning for at udvikle professionel dømmekraft er den anden forudsætning metodefrihed. PLF'er kan her være det forum, hvor læringsmål tolkes og udmøntes i praksis, og hvor undervisningsformer drøftes. Herigennem kan PLF'er sikre at den enkelte lærer opretholder professionel selvrespekt, og fællesskabet kan være et værksted og refleksionsrum (Qvortrup, 2015). Som den tredje grund til team organisering er, at det vigtigste enkeltstående element til at fremme elevernes læring, udvikling og trivsel er kompetenceudvikling af og for lærere, og denne sker praksisnært og i mindre grad eller slet ikke i kurser uden for undervisningskonteksten (Qvortrup, 2015). Blandt PLF-forskere peges der på, at en effektiv PLF-kultur kræver et minimum af (a) fælles værdier og normer, (b) samarbejde, (c) fokus på elevernes læring, (d) reflekterende dialog og (e) normer for eksplicit deling af praksis. Det fremhæves dog, at der ikke er én unik metode til at skabe et lærende fællesskab på en skole (Vangrieken et al., 2017).

I et aktionsforskningsprojekt af Casey \& Goodyear (2015) var målet, ud fra en gensidig interesse, at udvikle et praksisfællesskab blandt idrætslærere, som ønsker at inkorporere professionel udvikling i deres undervisning. Det var et langstrakt og krævende arbejde at etablere et praksisfællesskab, men det viste sig, at praksisfællesskabet var en nøgle til fortsat professionel udvikling. Hovedstyrken i praksisfællesskabet var, at en forsker, som ikke var indlejret i den daglige praksis, gennem dialogisk aktivitet kunne udfordre lærernes forståelse og bringe relevant viden ind i praksisfællesskabet.

I PLF’er ses i forhold til faglig læring ofte de samme mål, strategier og koncepter 
som i praksisfællesskaber, og i forskning anvendes begge udtryk ofte for det samme fænomen (Casey \& Goodyear, 2015; Vangrieken et al., 2017).

Det teoretiske grundlag for PLF er teorien om praksisfælleskaber. Disse eksisterer, ifølge Wenger (1999), fordi mennesker er gensidigt engagerede og deltager i handlinger, hvor mening kan forhandles ved deltagernes evne til at påvirke og blive påvirket. Meningsforhandlingerne er udgangspunktet for deltagernes fælles virksomhed, bestemt af de aktiviteter deltagerne gennemfører. Over længere tids gensidigt engagement i deltagernes fælles virksomhed skabes der gennem disse aktiviteter et repertoire, som er fællesskabets ressourcer i form af rutiner, fortællinger, jargon og artefakter (Wenger, 1999). Forhandlingen involverer et samspil mellem to processer, "deltagelse" og "tingsliggørelse". Deltagelse former oplevelser og fællesskabet ved at skabe ny mening og erkendelse imellem deltagerne, og dermed opnår de læring. Tingsliggørelse henviser til processen, der former erfaringer ved at skabe objekter, og det indbefatter både processen og produktet. Således defineres et lærende fællesskab som en gruppe mennesker, der deler en problemstilling eller en lidenskab om et emne, og som udvider deres viden og ekspertise på området ved løbende at samarbejde (Wenger, McDermott, \& Snyder, 2002). Da idrætslærerne ved GUX Sisimiut deler lidenskaben for idrætsundervisning og ønsket om at påvirke og udvikle deres praksis, finder vi teorigrundlaget brugbart.

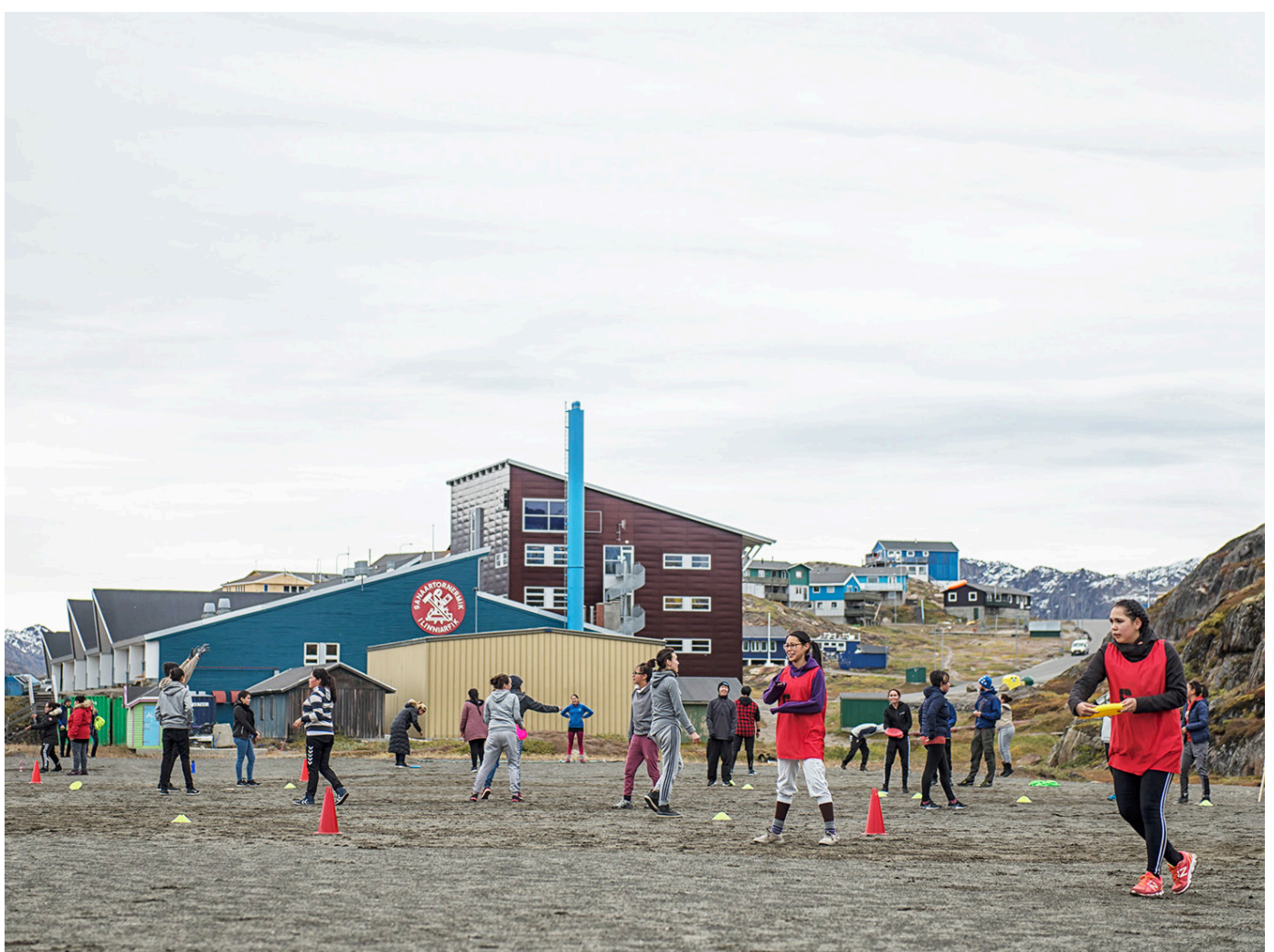




\section{Undersøgelsens rammebetingelser IKIIN}

Ud over den dobbeltkulturelle udfordring er gældende, er gymnasiebekendtgørelsen præmis for projektet. I 2012 gennemførtes af det grønlandske departement for Uddannelse, Kultur, Forskning og Kirke (IKIIN) en reform af det grønlandske gymnasium (GUX-reformen). Idéen i reformen var 'eleven i centrum' og tilpasning til elevens kulturelle baggrund (IKIIN, 2016). I reformarbejdet blev der lavet nye læreplaner for idræt, og de har været grundlaget for vores udvikling af undervisningskulturen, der imødekommer elevernes kulturelle diversitet og udfordringer bedre (IKIIN 2012, s. 119-120). Dette har også været en del af grundlaget for udvikling af vores PLF.

\section{GUX Sisimiut}

Konteksten for aktionsforskningen er gymnasiet GUX Sisimiut, der er ét ud af fire gymnasier i Grønland. Der er ca. 250 elever på gymnasiet. Gymnasiet blev oprettet i 2000 som HTX, hvor der ikke blev undervist i idræt. I 2010 blev der, parallelt med HTX-studieretningerne, indført 2 almene STX-studieretninger med idræt på C-niveau. I 2012 overgik gymnasiet med reformen til "GUX" (enhedsgymnasiet for Grønland), og i forbindelse hermed blev der indført et obligatorisk 25-timers grundforløb "idræt fællesfag" for alle studieretninger (KTI, 2017). Med idrætsfagets korte historie og pågående ændringer, samt at der har været stor udskiftning blandt idrætslærerne ved GUX Sisimiut, betegnes idrætshistorien ved GUX Sisimiut som kort og omskiftelig. Dette har ligeledes været en præmis for aktionsforskningen.

\section{Medvirkende i projektet}

Aktionsforskningen blev koordineret i et samarbejde mellem idrætsfagkonsulenten fra IKIIN, rektor ved GUX Sisimiut og medforfatter, der på daværende tidspunkt var specialestuderende. Derefter involveredes idrætslærerne ved GUX Sisimiut. Specialevejleder har været sparringspartner under aktionsforskningen i specialeprojektet. Idrætslærerteamet ved GUX Sisimiut bestod af:

1. En idrætslærer med 4 års erfaring på et dansk gymnasium og 1 års erfaring som lærer ved GUX Sisimiut

2. En idrætslærer med 1 års erfaring som lærer ved GUX Sisimiut

3. En idrætslærer med 1 års erfaring som lærer ved et gymnasium i Danmark (vedkommende indgik først i arbejdsgruppen pr. 1. august, hvor det første møde i gruppen blev afholdt ultimo maj).

4. En idrætslærer (andenforfatter og tidligere specialestuderende) med 4 års erfaring som lærer ved GUX Sisimiut. 
Idrætslærerteamet besluttede i fællesskab at de fem 1.G klassers introduktionsforløb, svarende til 5x2 timers undervisning, skulle være genstand for projektets forskning.

Rektor og lærerne blev informeret mundtlig og skriftlig om projektets mål, indhold og aktiviteter og gav skriftligt samtykke, og blev informeret om muligheden for at trække sig fra studiet. Alle navne er af etiske hensyn anonyme i artiklen, og samtidig indgår tre ud af fire lærere og vejleder i forfatterkredsen til artikel.

For at validere fundene i projektet involverede, som anbefalet i AF, specialestuderende de øvrige idrætslærere i analyserne for at opnå enighed om forståelser og tolkninger af projektets fund. Dette skete både til formelle møder og gennem uformelle samtaler på lærerværelset (Duus et.al, 2012). Under efterfølgende møder (se tabel 1), i anden refleksionsfase, faciliteret sammen af specialestuderende (andenforfatter) og førsteforfatter, blev temaet for nærværende artikel fundet. Disse meta-analyser var med til at skabe dybere forståelser for specialet og de udfordringer, der var i at medvirke i aktionsforskningsprojektets aktiviteter samt udviklings- og læreprocesser.

\section{FORSKNINGSSTRATEGI OG METODER}

Aktionsforskning (AF) opererer mellem tænkning i forhold til og handling i praksis, og indbefatter tiltag med afsæt i praksis, oftest i et samarbejde mellem praktikere og forskere (Rönnerman, 2013). AF bygger på demokratiske processer, hvor dem, man forsker med, i større eller mindre grad er med i projektet. Det involverende perspektiv ses $i$, at et samarbejdende demokratisk partnerskab er et bagvedliggende ideal. Derfor vil dem, der har eller ejer et problem, være involveret i at definere og løse det, og hvordan parterne er inddraget i AF kan have væsentlige demokratiske konsekvenser (Coghlan \& Brannick, 2007). Denne tilgang var gældende for den konkrete udvikling af en mere kulturel imødekommende introduktion til idrætsundervisningen.

Ifølge Cassel \& Johnson (2006) er et hovedtræk i AF, at der bliver udviklet (praksis)teori ud fra data i modsætning til traditionel positivistisk videnskab, hvor data skal be- eller afkræfte en på forhånd udvalgt teori. Og tilgangen i denne første del af AF-arbejdet placeres delvist mellem det deltagerinvolverende og den i Lewinsk forstand hypoteseafprøvende tilgang (Cassel \& Johnson, 2006), hvor interessen, specielt fra forskerens side, har været at involvere alle aktører, lærere såvel som elever, og hvor projektejers interesse i højere grad har været udvikling af en konkret brugbar (eksemplarisk og troværdig) praksis. Der har således været forskellige værensfilosofiske (ontologiske) og erkendelsesteoretiske positioner i spil i den gennemførte AF-praksis.

De efterfølgende metaanalyser af hele forløbet, som nærværende artikel be- 
lyser, afdækkede i nogen grad aktørernes forskellige interesser. Denne del af aktionsforskningen, bestående af metaanalyser, positioneres i højere grad i en dekonstruktivistisk tilgang funderet i et postmoderne epistemologisk og ontologisk ståsted. I denne tilgang til aktionsforskning er der plads til alternative fortællinger, og modstand belyses uden at gå ind for nogen præference, og det multivokale fremhæves gennem dekonstruktion for at skabe gennemsigtighed og begrænse diskursiv lukning (Cassel \& Johnson, 2006). Den dekonstruerende tilgang er i nogen grad blevet kombineret med en "Constructive Design Research" tilgang (Koskinen, 2011), hvor en efterfølgende konstruktion af (forestillingen om) PLF giver en højere grad af håndgribelighed til aktionsforskningens læringspotentialer.

\section{Cykliske processer}

Et hovedtræk ved AF er de iterative processer, forstået ved at forskningen forløber over en række cykliske processer med en række faser i hver cyklus. Dette er illustreret i figur 1, der er inspireret af Coghlan and Brannick-modelen (2014). Ifølge Coghland og Brannick (2014) skelnes der mellem to cykliske processer: core action cycle og thesis action cycle. Et samlet AF-projekt kan, som det vises i figur 1, betragtes som én cyklus, og ifølge Coghlan og Brannick (2014) indeholder en cyklus

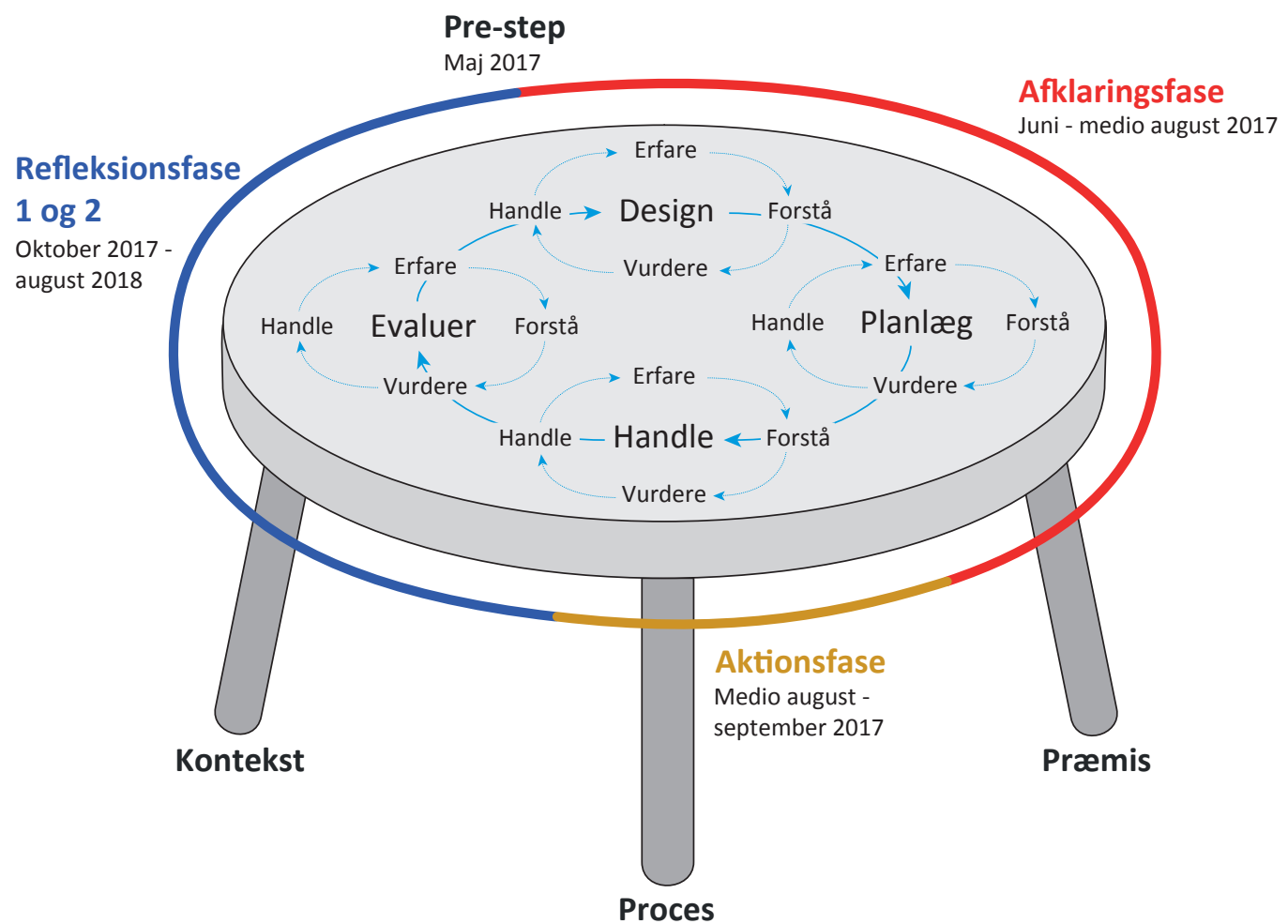

Figur 1. Aktionsforskningsmodel for GUX Sisimiut udvikling af kulturel imødekommende idrætsundervisning og PULP 
diagnosticering, planlægning af handling, at udføre handling (aktion) og evaluere handling (forskning). Samtidig kan enkelte faser og enkelte aktiviteter også forstås som bestående af cyklusser, hvor hver mikro-cyklus omfatter aktiviteterne erfare, forstå, vurdere og handle, og hvorigennem læring tolkes og skabes i hvert element $i$ et samlet projekt. Yderligere kan der i et aktionsforskningsprojekt indgå flere interventioner, (iterationer) med henblik på at udvikle praksis. I følge Coghlan and Brannick (2014) indledes processen med et pre-step efterfulgt af, som beskrevet, de fire trin: design, planlægning, aktion og evaluering, og som samlet udgør grundforståelsen af processen, et af de tre ben i Coghlan and Brannicks skammel-model. I pre-step reflekteres over projektets hvorfor og hvad samt hvilke præmisser, der er for projektet, og hvilke udviklingsperspektiver det indebærer. Det vil sige forhandlinger om, hvem er med, samt på et overordnet plan at udvikle formålet, målet, evt. problemstillinger og afklare det principielle design. I pre-step fasen afklares med fagkonsulenten i idræt fra IKIIN, hvilken interesse den centrale grønlandske administration har i projektet, og rektor ved GUX Sisimiut giver sin fulde opbakning til projektet blandt andet ved at afsætte timer til forskningen. Desuden udvælges den gruppe af mennesker, som skal indgå i projektet, og en rolleforhandling indledes, hvem der er forsker, og hvem der er medforskere samt eventuel sparringspartner.

Core action cycle har været grundlag for udvikling af en undervisningskultur, som imødekommer elevernes kulturelle udfordringer ved mødet med gymnasiets idrætsundervisning. Mens refleksioner i thesis action cycle førte til antagelser om udvikling at et professionelt læringsfællesskab, og som idrætslærerteamet ved GUX Sisimiut vurderes at have været medvirkende til udvikling af under- og efter deres arbejde med core action cycle.

\section{Thesis action cycle}

Thesis action cycle er en meta-cyclus, der forløber parallelt med core action cycle i AF'en og tager form af meta-refleksioner og -analyse over core action cycle. Disse er refleksioner over den viden man genererer, de igangsatte handlinger og den skabte viden, når man konstruerer, planlægger, gennemfører og evaluerer aktionerne (Coghland \& Brannick, 2014). Der stilles i metaanalysen spørgsmål til grundlæggende antagelser og præmisser i relation til processen. Disse refleksioner og analyser har i særlig grad bidraget med viden om PLF. Tilgangen i AF'en blev tilpasset de faktiske forhold ved at lade virkeligheden være medbeslutningstager $i$, hvad der var muligt - og aktionsforskningen har dermed, ved siden af de erkendelsesteoretiske refleksioner, været præget af en pragmatisk tilgang. Det affødte, at der blev arbejdet ud fra en trefaset model, men hvori de fire faser fra AF spejles. De tre faser var, se figur 1; afklaringsfasen, aktionsfasen (undervisning) og refleksionsfasen. 
Som det ses i figur 1, strækker refleksionsfasens aktiviteter sig over 3/4 år og er todelt. Første del, oktober 2017 - februar 2018, var specialeskrivningen, og projektejers fortrinsvis individuelle analyse, men hvor der også blev afholdt analyse- og valideringsmøder. Anden del, frem til august 2018, havde fokus på meta-analyser, hvor hele forskergruppen har indgået, og hvor forløbet blev dekonstrueret, og refleksionerne her fra førte til antagelser om udvikling af et PLF.

\section{Gennemførte aktiviteter og data-generering i GUX aktionsforskningen}

I afklaringsfasen afholdtes 6 møder, hvor der arbejdes med at fastlægge formål, indhold og proces, herunder elevinvolvering i projektet. I aktionsfasen afvikles 4 dobbelt-lektioner + et stævne (boldbasis finalen), og der indgik øvelser, hvor elever var involveret i udvikling af undervisningskulturen. Efter aktionerne var der post-aktionsrefleksioner mellem lærerne og specialestuderende. Faserne vist i figur 1 er i tabel 1 yderligere uddybet med de specifikke aktiviteter.

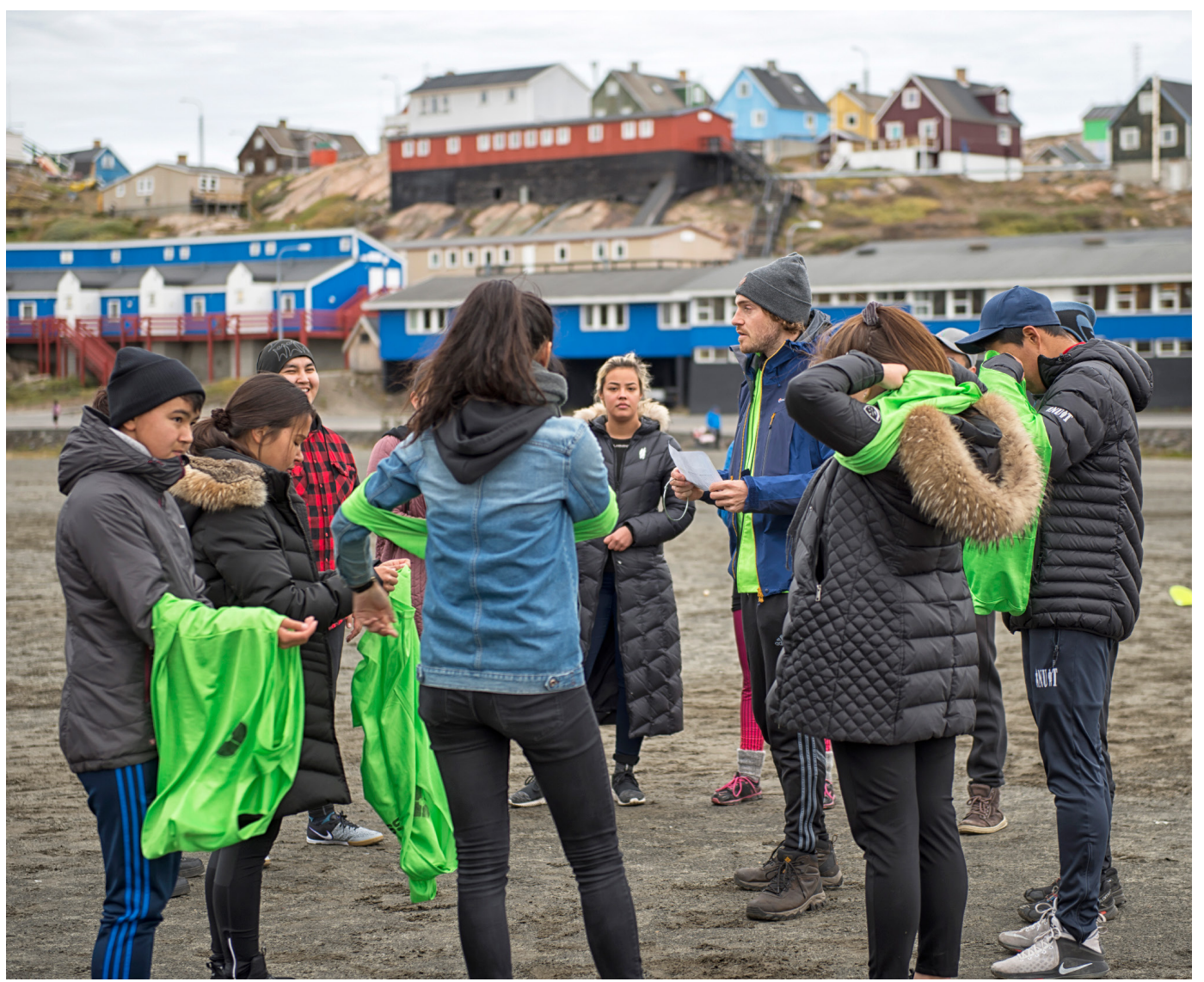


Tabel 1: Overblik over gennemførte forskningsaktiviteter i interventionsdelen samt i refleksionsfase 1 og 2.

\begin{tabular}{|c|c|c|c|}
\hline Fase & Aktivitet & Data & Undersøgelse \\
\hline Pre-fase & $\begin{array}{l}\text { Møder med ledelse, IKIIN og efterfølgen- } \\
\text { de kollegaer, øvrige idrætslærere }\end{array}$ & Møde-log & $\begin{array}{l}\text { Find mulighedsrum og } \\
\text { hvad kan undersøges? }\end{array}$ \\
\hline Afklaringsfase & $\begin{array}{l}\text { Møde 1-6: Fælles forståelse af aktions- } \\
\text { forskning etableres og formål, elevinvolve- } \\
\text { ring og aktiviteter debatteres, forhandles } \\
\text { og udvikles. Sent i afklaringsfasen blev } \\
\text { idrætsaktiviteten valgt (Planlægning), ud } \\
\text { fra et tidligere gennemført 'ultimate- } \\
\text { forløb', og tilpasset i forhold til de udvikle- } \\
\text { de værdier og principper. }\end{array}$ & $\begin{array}{l}\text { Møde-log samt } \\
\text { optagelse af } \\
\text { mødeaktiviteter } \\
\text { og vejledninger + } \\
\text { transskribering } \\
+ \text { andenforfatters } \\
\text { refleksions-log }\end{array}$ & $\begin{array}{l}\text { Hvilken kontekst og hvilke } \\
\text { præmisser er grundlag } \\
\text { for projektet, og hvad er } \\
\text { muligt under specialets } \\
\text { rammer? } \\
\text { Hvilke værdier, principper } \\
\text { og aktiviteter i under- } \\
\text { visningen? }\end{array}$ \\
\hline $\begin{array}{l}\text { Undervisning } \\
\text { - alias } \\
\text { aktionsfase }\end{array}$ & $\begin{array}{l}\text { Lektion 1: Introduktion til idræts- } \\
\text { undervisning } \\
\text { Lektion 2: Elevinvolvering med reflek- } \\
\text { sionsøvelse over den gode undervis- } \\
\text { ningskultur } \\
\text { Lektion 3: Elever udvikler normer for god } \\
\text { undervisning } \\
\text { Lektion 4: Undervisning på baggrund af } \\
\text { normer } \\
\text { Lektion 5: Finalestævne i ultimate } \\
\text { gennemføres, og eleverne inddrages i } \\
\text { afviklingen og evalueringen. } \\
\text { Møde 7-9: Løbende forhandling af elev- } \\
\text { involvering og aktiviteter i udvikling af un- } \\
\text { dervisningskulturen samt fælles feedback } \\
\text { om undervisningen. }\end{array}$ & $\begin{array}{l}\text { Møde-log samt } \\
\text { optagelse af } \\
\text { mødeaktiviteter og } \\
\text { vejledninger. } \\
\text { Observation af } \\
\text { undervisning og } \\
\text { fælles refleksion } \\
\text { og interviews + } \\
\text { transskribering } \\
\text { og andenforfatters } \\
\text { refleksions-log }\end{array}$ & $\begin{array}{l}\text { Hvordan værdier og } \\
\text { principper ses konkre- } \\
\text { tiseret i den aktuelle } \\
\text { undervisning? } \\
\text { Hvordan lærere sammen } \\
\text { reflekterer og giver } \\
\text { feedback? } \\
\text { Hvordan eleverne invol- } \\
\text { veres i undervisningen, } \\
\text { samt i udviklingen af en } \\
\text { god undervisningskultur? } \\
\text { Hvilken kultur mener } \\
\text { eleverne der skabes? }\end{array}$ \\
\hline $\begin{array}{l}\text { Refleksionsfase } \\
1\end{array}$ & $\begin{array}{l}\text { Afholdelse af evalueringsmøde med } \\
\text { projektgruppen. } \\
\text { Analyse af data og møde med projekt- } \\
\text { gruppen om validering samt justering } \\
\text { af og yderligere bidrag til resultater, og } \\
\text { refleksion over etiske forhold. } \\
\text { Endelig færdigskrivning og bedømmelse } \\
\text { af speciale. }\end{array}$ & $\begin{array}{l}\text { Møde-log samt } \\
\text { optagelse og } \\
\text { transskribering af } \\
\text { vejledninger med } \\
\text { specialevejleder. }\end{array}$ & $\begin{array}{l}\text { Hvilken undervisnings- } \\
\text { kultur blev udviklet, og } \\
\text { hvordan gik det i konkret } \\
\text { praksis? } \\
\text { Sekundært hvilken læring } \\
\text { har specialestuderende } \\
\text { opnået? }\end{array}$ \\
\hline $\begin{array}{l}\text { Refleksionsfase } \\
2\end{array}$ & $\begin{array}{l}\text { Udkast til abstract for artiklen, som } \\
\text { konkret grundlag for videre analyser og } \\
\text { drøftelser. } \\
\text { Skype-møde om udformning af et legitimt } \\
\text { fokus for nærværende artikel - efterføl- } \\
\text { gende fokus på PLF. } \\
\text { To møder med yderligere metarefleksioner } \\
\text { og analyser af aktionsforskningsproces- } \\
\text { sen og tydeligere perspektiver på forhold } \\
\text { vedr. etablering af PLF. }\end{array}$ & $\begin{array}{l}\text { Analyse af data } \\
\text { og validering af } \\
\text { analysefund og } \\
\text { metaanalyse af } \\
\text { prefase, kontekst, } \\
\text { proces og præmis } \\
\text { for forskningen. }\end{array}$ & $\begin{array}{l}\text { Hvilket problem har AF- } \\
\text { projektet løst, og i hvilken } \\
\text { grad er det lykkedes? } \\
\text { Hvilken læring har } \\
\text { gruppen opnået gennem } \\
\text { processen i aktionsforsk- } \\
\text { ningen som den har været } \\
\text { igennem? }\end{array}$ \\
\hline
\end{tabular}




\section{Journalføring i projektet (møde-log mm.)}

Journalføring har været anvendt i både core action cycle og thesis action cycle. Den tog form af noter om, hvad der skete i praksis, blandt andet gennem moderat deltagerobservation, efter samtaler med specialevejleder, efter møder og uformel samtale i arbejdsgruppen om projektet (Spradley, 1980). I theisis action cycle tog det form af noter som tydeliggjorde, hvordan der er blevet forsket i projektet.

Ifølge Spradley (1980) observerer deltagerobservatøren aktiviteter, mennesker og fysiske aspekter af situationerne, imens han eller hun deltager og nedskriver feltnoter over dette.

Spradley (1980) beskriver 6 forskellige typer af deltagelse, som går fra fuldstændig deltagelse til ikke-deltagelse, og i nærværende studie har vi som forskere bevæget os mellem:

På den ene side fuld deltagelse, hvor forskeren undersøger sociale situationer, som vedkommende er en del af. Derved forsker forskeren i sin egen sociale praksis.

På den anden side moderat deltagelse, hvor forskeren befinder sig imellem fuldstændig deltagelse og ikke-deltagelse. Uden på noget tidspunkt at nå de to yderpositioner søger forskeren at opretholde en balance imellem at være aktivt deltagende og træde tilbage for bedre at kunne observere den sociale situation (Spradley, 1980).

Tre af de fem undervisningsfællesskaber (lærer og elever sammen), som den specialestuderende gennemførte aktionsforskning med, var klasser, som hans tre kollegaer underviste. Med disse undervisningsfællesskaber fremstillede han data ved moderat deltagerobservation, mens hans lærerkollegaer stod for at gennemføre undervisningen og aktionerne. To undervisningsfællesskaber var klasser, hvor den specialestuderende selv underviste. Her var han fuldt deltagende under observationerne, og havde i mindre grad mulighed for at træde tilbage og reflektere på afstand. Feltnoter herfra blev nedskrevet umiddelbart efter hver enkelt observation.

I thesis action circle blev noter nedfældet på fælles tavle undervejs i analyserne og afklaring af, hvad læringsforløbet havde medført, og hvilken fælles forståelse og modstridende opfattelser der var, og der kunne argumenteres for, og som der kunne opnås indblik i. Her blev førsteforfatter, forhenværende vejleder og udefrakommende akademiker, til stadighed udfordret på sine antagelser, og således var denne proces i sig selv med til at afdække, at der kunne være tale om et professionelt læringsfællesskab. Konsensus blev kun delvist opnået, og forståelse for hinandens positioner udvikledes ved, at vi udfordrede hinanden og arbejdede på at se den fælles proces gennem hele forløbet og vores egen proces udefra og som læring.

Vores påstand vil derfor være, at det tidligere magtforhold, der havde været mellem vejleder og specialestuderende, ikke længere havde afgørende indflydelse på artiklens resultater. Samtidig havde lærerkollegaerne under hele aktionsforlø- 
bet løbende udfordret specialestuderendes forforståelse og opfattelser af aktionsforskning. Og disse var i nogen grad medieret af og provokeret frem af vejleder. Vi er derfor af den opfattelse, at de demokratiske magtrelationer til stadighed har være udfordret, men måske ikke altid lige åbne, i det samlede forløb.

\section{Forskningsinterviews}

Vi forstår samtalen som kvalitativ datakilde, hvorfor både arbejdsgruppemøderne og postrefleksionsinterviews ses som kvalitative forskningsinterviews (Coghlan \& Brannick, 2014). Et interview er i bogstavelig forstand en udveksling af synspunkter mellem to personer, der taler sammen om et emne af fælles interesse (Kvale, 2009). Inden for det brede spekter af tilgang til aktionsforskning har interviewet en tendens til at være åbent og ustruktureret. Interviewet fokuserer på, hvad den interviewede har på hjerte frem for kun at be- eller afkræfte hypoteser, som aktionsforskerne kan have (Coghland \& Brannick, 2014). Netop de ustrukturerede interviews i projektet har været den væsentligste kilde til fremstilling af data i arbejdsgruppen.

\section{Analyse}

Data er analyseret tematisk med hjælp fra Braun m.fl. (2016) seks-trins model. Den tematiske analyse er et kvalitativt værktøj, der anvendes til at identificere mønstre $i$ form af temaer $i$ et datasæt og give en nuanceret beskrivelse og fortolkning af temaer. Metoden består af: data familiarisering, kodning foretaget med NVIVO, udvikling af temaer, gennemgang, navngivning og renskrivning.

Meta-analysen, vist i figur 2 med de grå bokse, er en udvikling af analysetræet for den tematiske analyse, hvor der er tilføjet et ekstra niveau øverst og et til højre i kodetræet. De mange relationer mellem analysens temaer og kategorier viser, at det metaanalytiske niveau er komplekst og indbefatter alle elementer i projektet fra ydre pålagte rammer til personlige oplevelser. Ud fra kompleksiteten i analysen har vi fundet det informativt at præsentere resultaterne af metaanalyserne som procesfortællinger med bemærkninger. Fortællingerne bygger på en kondensering af noter og interviews, som har været foretaget undervejs i undersøgelserne, samt en genkaldelse af emotionelle oplevelser projektet har givet (Kvale 2000). Samtidigt har Sparkes (2002) koncept om modificerede realitetsfortællinger (modifying realist tales) formuleret i 3.-person bidraget til vores forståelse af, hvordan processen kunne formidles. Dette for i højere grad at distancere os og dermed give os mere rum til kritisk refleksion. Med det finder vi, at vi gennem den eksperimenterende form formidler resultaterne af forskning ud fra kvalitetskriterier, der tager højde for evokativitet, og således fremmer mentale billeder, minder eller følelser relateret til temaet. Og disse fortællinger, mener vi, gør dekonstruktionen mere 
umiddelbar, levende og troværdige, og dermed i nogen grad kan medtænke princippet om refleksivitet - subjektiv tilstrækkelighed - om hvad er forskerens forhold til hans / hendes formål med forskning (Heikkinen, 2007).

\section{LAERERLAERING}

For at give et indtryk af arbejdet med udvikling af undervisningen og således elevernes læring refereres indledningsvis udvalgte resultater fra core action cycle'. Derefter et eksempel på en fortælling i 3. person, der viser data fra theisis action cycle, og det fører over i en mere generel præsentation af de fremanalyserede temaer / elementer om udvikling af et professionelt læringsfællesskab (PLF).

En lærer udtaler til et møde: "Der er en tydelig parallel mellem det gode boldspilsteam og den velfungerende klasse". Ved værdien "inklusion" forstås, at der bør skabes en undervisningskultur, der inkluderer alle eleverne i idrætsundervisningen. Citatet ovenfor kommer fra et møde, hvor lærerne diskuterer boldspilsundervisning. Læreren ønsker at udvikle gode boldspil teams fordi "de har paralleller til den velfungerende klasse". De vil udvikle en idrætsundervisning, der fordrer at klasserne bliver udviklet som velfungerende teams, hvor det er nødvendigt at alle deltager og bliver en inkluderet del af teamet, og lærerne ønsker det som en fast del af det fælles repertoire.

Allerede fra de første møder kredser mange af forhandlingerne om inklusion sammen med en værdi om i undervisningen at skabe god energi sammen med eleverne, men først i aktionsfasen blev det tydeligt, hvordan dette kunne gøres. Det ses blandt andet ved at:

Der er god energi i frisbeeøvelserne. Alle spiller med hinanden. En elev kommer 40 minutter for sent med kaffe, kage og mobil i hånden. (Hun ser virkelig sløv ud). "Kom og vær med" (smiler læreren og taler imødekommende til eleven). To minutter efter er hun med og deltager - hun har endda idrætstøj på.

Af observationen fremgår det, at den gode energi bruges til at inkludere eleven i fællesskabet. Eleven udstråler med sit kropssprog, at hun ikke er undervisningsparat og klar til at deltage aktivt, hvilket strider imod de tydelige rammer, som læringsfællesskabet på dette tidspunkt bør tage udgangspunkt i. Disse data i form af mødenoter og observationer viser eksempler på, hvordan praksis blev udviklet til introforløbet i idræt. 


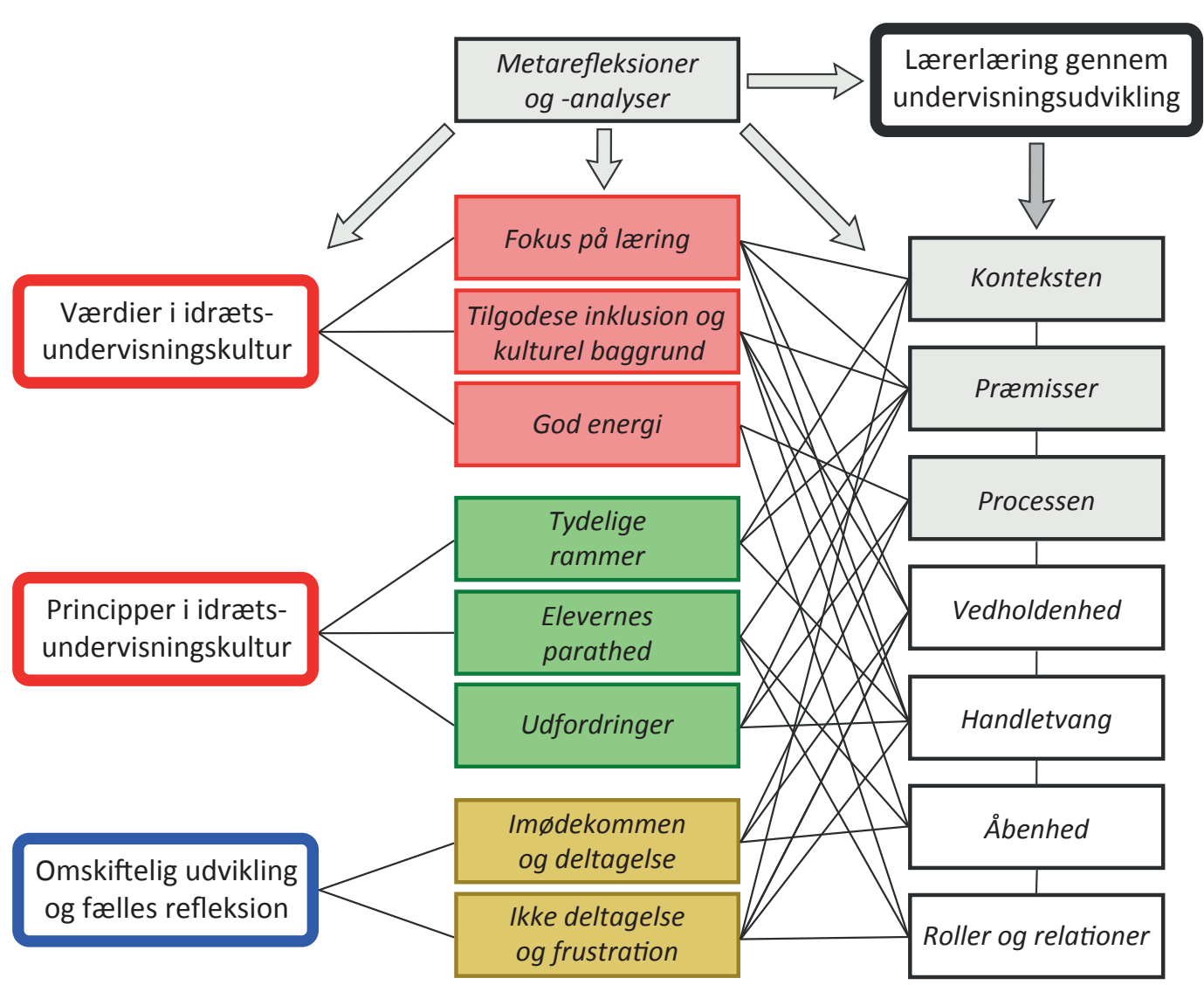

Figur 2: Oversigt over resultater af meta-analysen $i$ theisis action cycle.

Samlet førte det til, at der til forløbet med introduktion af idræt for GUX 1.G eleverne blev udviklet en undervisningskultur byggende på tre værdier, 'fokus på læring', 'tilgodese inklusion og kulturel baggrund' og 'god energi'. For at praktisere dette i udvikling af den konkrete undervisningskultur blev følgende tre principper etableret; 'tydelige rammer', tage højde for 'elevers parathed' og 'udfordringer'. Det viste sig, gennem post-refleksioner, at lærernes nye måder at imødekomme eleverne, ved at undervise ud fra de tre principper og med udgangspunkt i de tre værdier, kunne have positiv indflydelse på elevernes deltagelse i undervisningen. Modsat viste nogle situationer i undervisningen også ikke-deltagelse blandt eleverne, hvilket medførte frustrationer blandt begge parter.

Resultaterne førte til konkrete handleforslag til lærere, der i fremtiden skal udvikle undervisningskulturen, og de er følgende:

1. Med udgangspunkt i resultaterne af undersøgelsen anbefaler vi, at lærerne giver sig tid til at forhandle, hvilke værdier for undervisningen der bedst muligt imødekommer elevernes kulturelle udfordring. 
2. En nøgle til at løse de kulturelle og sproglige udfordringer, som gymnasiefremmede elever kan møde, er at lade undervisningen tage udgangspunkt i tydelige didaktiske principper, så eleverne oplever, at der er tydelige rammer for deres deltagelse i undervisningen. Disse bør støttes af værdier, som lærergruppen udvikler.

3. På længere sigt anbefaler vi at involvere eleverne i en meningsforhandling af, hvordan undervisningskulturen bør udvikles ved hjælp af en dialogbaseret tilgang til undervisningen. Men da gymnasiefremmede elever kan være sprogligt udfordrede, bør graden af åbenhed i dialogbaserede refleksioner tilpasses løbende til elevernes parathed i forhold til at løse åbne opgaver. At gå frem efter anbefaling 1 og 2 er således en forudsætning for på lang sigt, at kunne forhandle undervisningskulturen med eleverne.

Ud fra den proces vi har været i gennem, og med henblik på at udvikle en undervisningskultur, der imødekommer elevernes kulturelle udfordringer, belyser vi vores læring, vi som lærere og forsker og som forskningsteam har opnået.

\section{Data fra analyse af Thesis action cycle}

I første omgang benævnte vi temaet rolleafklaring.... og følgende viser NN's fortælling herom (specialestuderende - tog opgaven; skriv fra hjertet din fortælling om forløbet, gerne hvor du ser på det udefra):

Der har været en del frustrationer knyttet til vores samarbejde om at udvikle idrætsundervisningen. I løbet af særligt afklaringsfasen men også i projektets øvrige faser, brugte NN (specialestuderende) og kollegaerne lang tid på at lægge rammer og søge efter en retning for projektet. Som en af kollegaerne sagde på et møde fem måneder efter, at projektet blev afsluttet:

"Der var et speciale der skulle skrives, det skulle skrives. Samtidig skulle vi deltage. På den ene side sagde projektejeren, at vi skulle gøre det på en bestemt måde. Men på den anden side var det ligesom en tåge vi rakte ud $i$. Vi prøvede at gøre det projektejeren sagde, men det føltes som om der ikke var nogen tydelig retning for det, så vi vidste ikke hvad vi skulle gribe efter i denne tåge."

Citatet beskriver meget rammende usikkerheden, forskergruppen har følt igennem projektet. Projektejeren befandt mig i et vakuum imellem forskellige roller, "rollen som forsker" "rollen som specialestuderende" med "hjælp" fra vejleder og "rollen som idrætslærer". Samtidig påtog projektejer sig et ansvar for den overordnede koordinering af projektet, og som en følge heraf smittede en stor del af den usikkerhed, som projektejer følte, af på de øvrige idrætslærere og blev dermed en del af selve processen.

Senere skriver projektejer: "I et spændingsfelt mellem den styrende rolle som 
koordinator for projektet og de øvrige læreres frustration over de diffuse aspekter af projektet, brugte forskergruppen for lang tid på at tale om aktionsforskningsmetodiske indhold og for lidt tid på at diskutere og forhandle udvikling af idrætsundervisningen."

Set retrospektivt er det vigtige data, som efterfølgende har ført forskerteamet frem til en dybere forståelse for, hvordan et forskerteam kan / skal samarbejde og indgå $i$ et læringsfællesskab.

Ovenstående skriver projektejer, og disse refleksioner var med til at afdække de mange divergerende interesser der var, og som skulle varetages gennem aktionsforskningen. Samlet førte denne og lignende fortællinger til nedenstående elementer / temaer i udvikling af et PLF.

\section{Vedholdenhed}

Indledningsvis i processen havde den specialestuderende, som projektejer, indtaget en relativ ambitiøs og bestemmende rolle i AF-designet, hvor målet var at udvikle undervisningskulturen med en høj grad af elevinvolvering. Samtidig og løbende indgik han i demokratiske forhandlinger med idrætskollegaerne om formålet og de elevinvolverende elementer. Ønsket var at anerkende og bruge lærernes undervisningserfaringer i projektet. Fra kollegaernes side, og med specialekonteksten, var der samtidigt et ønske om at komme projektejer i møde, 'at få specialet gennemført'. Derfor forventede kollegaerne, at projektejeren ville definere projektets formål, mål og rammer tydeligt. Kort sagt - 'hvad vil du have, vi skal gøre?' Ikke desto mindre, og med det demokratiske udgangspunkt i AF, brugte arbejdsgruppen megen tid og energi på forhandlinger om, hvad de bedst muligt kunne tage ejerskab til i de elevinvolverende elementer i designet, hvor eleverne skulle inddrages i udvikling af undervisningskulturen. I den proces holdt projektejeren sig ambitiøst og 'vedholdent' til idéen om, at elevinvolvering var nøglen til at sikre udvikling og ny viden i udvikling af undervisningskulturen. De gode intentioner til trods, blev det vanskeligere og vanskeligere for resten af lærerne at tage ejerskab til den elevinvolverende tilgang. Det førte til flere iterationer i afklaringsfasen, hvor specialestuderende løbende justerede ud fra lærernes inputs og diskuterede designet med specialevejlederen, der talte for elevinvolvering. Resultatet blev, at den specialestuderende gennemførte de elevinvolverende elementer på egen hånd, og positivt formuleret kan det hævdes, at han derved forsøgte at optræde som rollemodel.

\section{Handletvang}

Med datoen for skoleårets start rykkende hastigt nærmere og dermed igangsættelse af aktionsfasen, og en implicit udefra pålagt 'handletvang', indså projektejer (den specialestuderende) og de øvrige lærere, at de ikke var i stand til at gennem- 
føre projektet med det design, som han vedholdent havde lagt op til. Han valgte derfor at neddrosle ambitionerne i forhold til elevinvolvering, men vedblev med at indsamle data om den fælles udviklingsproces, som idrætslærerne fortsat befandt sig i. Samtidigt blev der med projektejeren som anker, og med hans vedholdenhed, gennemført mindre elevinvolverende aktiviteter i udvikling af kulturen i idrætsundervisningen. I denne proces skiftede fokus også fra, hvordan undervisningskulturen kunne udvikles ved elevinvolvering, til hvordan lærerne i fællesskab og fra deres eget udgangspunkt kunne udvikle kulturen i undervisning. Dette skift i fokus kan ses som et vigtigt vendepunkt i AF-Processen.

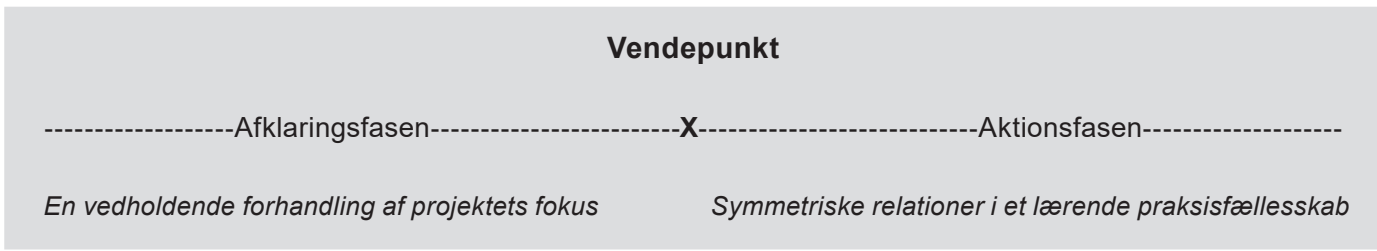

Figur 3: En vedholdende forhandling af projektets fokus

Ovenstående model viser vendepunktets placering i slutningen af afklaringsfasen og viser to temaer, som meta-noterne kredser om før og efter vendepunktet.

\section{Arbejde med relationer}

Det er tydeligt, at den implicitte handletvang gjorde, at projektejeren måtte give slip på sine ambitioner om fokus på elevinvolvering, og at det herefter blev hele lærergruppens ansvar at finde fokus for aktionerne. Herved ændrede tilgangen sig fra at være projektejerstyret med ønsket om elevinvolvering til at være demokratisk ledet af lærernes egne ønsker om udvikling af undervisningen. Dette medførte mere symmetriske relationer, hvilket bidrog til, at lærernes samarbejde var mere effektivt, og at lærerne herefter fik udviklet deres forståelse for undervisningskulturen i form af værdier og principper.

\section{Åbenhed}

Afklaringsfasen, som lå forud for vendepunktet, var altså en lang fase, hvor lærerne indgik i komplekse og til tider frustrerende forhandlinger af projektets fokus. Dette var dog en fase, som var mindst ligeså vigtig som den efterfølgende aktionsfase. Fordi forhandlingerne førte til vigtig læring om, at fokusset på elevinvolvering ikke viste sig muligt at føre ud i praksis, men til gengæld ændrede deres måde at anskue eleverne på og derved bidrog til vigtige erfaringer med, hvordan elever med kulturelle udfordringer til tider kræver trygge rammer indledningsvis i et læringsforløb. En forudsætning for lærernes læring i såvel afklaringsfasen som aktionsfasen har været, at begge faser har været karakteriseret af en gensidig åbenhed blandt lærer- 
ne. Dette kom til udtryk ved lærernes vilje til, på trods af at det krævede energi og frustrationer, at vedblive med at forholde sig åbent til projektejers vedholdende fokus på elevinvolvering, og at projektejer i den forbindelse var åben overfor de øvrige læreres måder at anskue elevinvolveringen på.

\section{DISKUSSION}

Specielt under refleksionsfase 2, og hvor de første aktioner blev gennemført, har det vist sig, at lærerne arbejder videre med værdierne og de didaktiske principper, som de har udviklet i core action cycle som udgangspunkt for deres undervisningspraksis i idræt på GUX Sisimiut. Som ofte set ved aktionsforskning, når den er afsluttet, genindtager den 'gamle' praksis dagligdagen (Fullan et al. 2006). Dette har umiddelbart ikke været tilfældet i nærværende projekt. Samarbejde har været et vigtigt karakteristikum ved processen med at udvikle disse værdier. Samtidigt har fokus på elevernes læring været en underlæggende præmis for alle de aktioner vi foretog. Vi finder, at udvikling af undervisningen sideløbende sigter på at udvikle lærerenes faglige dømmekraft og udvikling af den didaktiske praksis er centreret omkring elevernes læring. Samtidigt har udviklingsmøderne også været forum for at drøfte undervisningsformer, og den enkelte lærer har haft rum / værksted til at styrke og opretholde den professionelle selvrespekt (Qvortrup, 2015). Vi ser i mindre grad, at lærerne indgår i kompetenceudvikling, men i højere grad deler de kompetencer, teamet til sammen ligger inde med.

Ovennævnte værdier er i tråd med Vangrieken m.fl. (2017) værdier for at udvikle en PLF-kultur. Med dette udgangspunkt har vi som idrætslærere udviklet vores PLF ved GUX Sisimiut.

Nedenfor vil vi diskutere den læring, vi har opnået i den proces, der har forløbet over et år, og som har ført os frem til udviklingen af vores PLF.

Vendepunktet i processen knyttedes an til en stor del af lærernes læring. Deadline for undervisning førte til, at der 'tvinges' beslutninger igennem, der er grundlag for at handle og evaluere på, hvad der udvikles (Coghlan \& Brannick, 2014). I perioden hvor gruppen var presset på tid, var de bedst til at arbejde sammen. Og handletvangen som en håndfast præmis blev til en kærkommen hjælp, der førte til noget konkret at tale om i lærer-lærer refleksionerne. Vi mener, ikke desto mindre, at vedholdenhed omkring det elevinvolverende er vigtigt at stræbe efter. Idet vi mener, som Ovens m.fl. (2012), at en forudsætning for succes med at udvikle en fælles undervisningskultur anerkendt af eleverne er at arbejde på at nedbryde hierarkier, så relationerne, også til eleverne, kan være mest mulig ligeværdige.

Det interessante for vendepunktet i vores AF-projekt var, at det er i tråd med Ovens m.fl. (2012), at lærernes hierarki blev nedbrudt, og lærerne, trods forskellige erfaringer, udviklede et fællesskab, hvor de så hinanden som ligeværdige. Således 
skete der som følge af AF-processen en demokratisk udvikling, idet relationer i højere grad blev symmetriske. Alle tog i højere grad ejerskab for projektets design i form af proces og indhold (Coghlan \& Brannick, 2007). Samtidigt har den demokratiserende proces medført interesse i at bidrage til forskningen ved i fællesskab at skabe og validere den genererede viden i projektets forskning og dermed i sidste ende udviklingen af PLF. Lærernes deltagelse i processen efter vendepunktet kan, ud fra Wenger (1999), ses som karakteriseret af deltagelse og tingsliggørelse. Lærerne udviklede (tingsliggjorte) materialer og nedskrevne tilgange til undervisningen, hvilket var udgangspunktet for deres deltagelse i projektet, som førte til nye tilgange til idrætsundervisningen. Udviklingen af undervisningskulturen har således været lærernes grundlag for at deltage i handlinger, hvor meninger blev forhandlet og førte til udvikling af tingsliggjorte objekter (materialer og dokumenter om idrætsundervisningen), og som har afstedkommet nye former for deltagelse (ny undervisningspraksis) (Wenger, 1999). Igennem projektet har lærerne således udviklet et PLF med en fælles virksomhed om at udvikle undervisningskulturen til bedre at imødekomme elevernes kulturelle udfordringer. Selvom denne fælles virksomhed i vid udstrækning gjorde sig gældende for lærernes praksisfællesskab i løbet af projektets indledende faser, var særligt afklaringsfasen karakteriseret af en stor grad af frustration som følge af en manglende afklaring af projektets fokus. Således var det først i løbet af de efterfølgende refleksionsfaser, at lærerne ved fælles refleksion fik projektets resultater i form af temaer til at 'falde på plads'. Resultatet af core action cycle; at "værdibaseret undervisning er udgangspunktet for tydelige didaktiske principper" forstås som en fælles fortælling om, hvordan idrætslærerteamet praktiserer deres idrætsundervisning ved GUX Sisimiut. Det udviklede og tingsliggjorte undervisningsmateriale og dertil knyttede former for undervisningspraksis, som lærere gennemfører, kan, sammen med denne fortælling, forstås som eksplicitte ressourcer, der kan udgøre de første skridt i forhold til at skabe et fælles repertoire i idrætslærergruppen ved GUX Sisimiut.

Refleksionsfase 2 afsluttes først med udgivelsen af denne artikel. Der skulle altså gå mere end to år før de første skridt var taget i forhold til at etablere et PLF med et fælles repertoire. Dette ligger i tråd med Casey og Goodyear (2015), der fremhæver, at udvikling af PLF'er er et længerevarende og krævende arbejde. Men til gengæld er udvikling og etablering af PLF'er en vigtig nøgle til fortsat professionel udvikling. Det vil dermed fortsat kræve 'vedholdhed', 'åbenhed' og arbejde med 'relationer' at udvikle lærernes fortsatte 'lærerlæring gennem undervisningsudvikling' i PLF'en. Hvilket bør gøres ved fortsat at sætte tid af til meningsforhandlinger af den fællesvirksomhed om at udvikle undervisningskulturen til bedre at understøtte elevernes kulturelle udfordringer, og på sigt yderligere udvikle det elevinvolverende perspektiv. Vi ser i høj grad de gennemførte drøftelser i specielt afklaringsfasen præget af professionel tillid, hvilket ifølge Qvortrup (2015) indbe- 
fatter at være i stand til at tale åbent om succes'er og udfordringer, samt at vanskeligheder ikke er personrelateret, men kredser om udfordringer i en professionel praksis, hvor også dygtige lærere kan komme til kort. Her handler det om sammen at udvikle kompetencer, dele fremgangsmåder og strategier, for at skabe bedre læringsmuligheder for eleverne (Qvortrup, 2015).

Da ovenstående analyser har flere retninger, forekommer der ikke et entydigt akademisk erkendelsesgrundlag i artiklen. Vi ser, at der med den vedholdende interesse for at inddrage eleverne i udvikling af undervisningen er indikationer på en relativ positivistisk og hypoteseafprøvende tilgang, ikke mindst medieret af specialevejleder (Cassel \& Johnson, 2006). Gennem udviklingen af undervisningsforløbet ses en intension om i en inddragende proces at udvikle en fælles praksisteori. Dette synliggjort gennem de afklarende møder, hvor projektejer ikke skitserer en model for den introducerende undervisning. Som aktionsforskningen udspillede sig, hvor en række drøftelser i højere grad førte frem til en deltagerinvolverende og demokratiserende proces, fik magtrelationer mellem projektejer og de øvrige i teamet mindre og mindre betydning. Derfor kan argumenteres for at forløbet i nogen grad var participatorisk og frigørende (Cassel \& Johnson, 2006).

I de efterfølgende metaanalyser, hvor forskerteamets medlemmer fik mulighed for at bidrage med deres egne fortællinger i forløbet, blev de enkelte medforskeres roller synlige for hinanden, og dermed blev forløbet i nogen grad dekonstrueret, og indsigter i indbyrdes ståsteder blev synlige. Der kan dermed argumenteres for, at der i specielt metaanalyserne har været en i højere grad postmoderne erkendelsesinteresse (Cassel \& Johnson, 2006). Der hvor dette ontologiske og erkendelsesteoretiske ståsted ikke til fulde er konsistent, finder vi, er der, hvor PLF bliver designet og ikke blot er en dekonstruktion af sprogspil. Dermed kan der være tale om en abduktiv (emergerende) og konstruerende design tilgang, hvor erhvervede indsigter fører til en model og anbefalinger (Koskinen, 2011). Risikoen herved kan være, at på trods af de forskelle, der opstår fra dette fokus med brug af aktørerne subjektive betydninger, løber vi risikoen ved at arbejde ud fra designståstedet, det som mange filosoffer definerer som positivismens centrale epistemiske egenskaber, at vi benytte os af et neutralt observationssprog som forudsætning, og vi kan ende med at balancere på grænsen til essentialisme (Cassel \& Johnson, 2006). Dermed fjerner vi os fra den blotte erkendelsesinteresse til også at pege frem mod at udvikle alternative praksisformer, som ukritisk kan anvendes som ledelsesværktøjer. Vi stiller spørgsmål ved, om det er en ny tilgang til lærerjobbet, i hvilket det opleves som et kald at undervise og udvikle undervisning (Hein, 2013).

Et andet spørgsmål vi ønsker at stille er, om vi ved at anvende det danske PLF som erstatning for det engelske Professional Learning Community (PLC) ikke udvikler noget nyt og måske i sidste ende blot ender med en beskrivelse af processen, der i bedste fald kan indtage en eksemplarisk funktion. Det er ikke desto mindre 
en af aktionsforskningens fornemste opgaver. Vi hævder på ingen måde at have fundet det endelig svar og skitserer deri designtilgangens mulighed for løbende udvikling, og dermed vedgår vi os, at den praksis, vi er i og er medudvikler af, kan være befolket af hyper-virkeligheder (Cassel \& Johnson, 2006).

Med ovenstående kritiske betragtninger og refleksioner vil vi ikke desto mindre vove pelsen og nedenfor skitsere enkelte af vore læringspunkter i anbefalinger. Samtidig vil vi yderligere anbefale at kigge ind i Ågårds (2018) "Professionelle læringsfællesskaber", for yderligere anbefalinger til arbejdet med professionelle læringsfællesskaber.

\section{ANBEFALINGER}

Idrætslærergruppen anbefaler ved etablering af PLF at:

- Udpege en projektejer, der vedholdende fastholder ambitioner.

- Imødekomme konteksten og præmisserne som de er, eksempelvis ved at se mulighederne $\mathrm{i}$ handletvangen som undervisning er underlagt.

- Arbejde med og udvikle egen og andres åbenhed, og deri at sætte ord på og arbejde med roller, der fremmer symmetriske relationer.

- Åbenhed over for kollegaerne som eksperter er befordrende, herunder vedholdende at søge nye forståelser og ny viden til udvikling af undervisning.

Samtidigt kan, som vist med refleksionsfase 2, tid til at komme på afstand af erfaringer og eftertanke være en værdifuld kilde til læring i egen praksis.

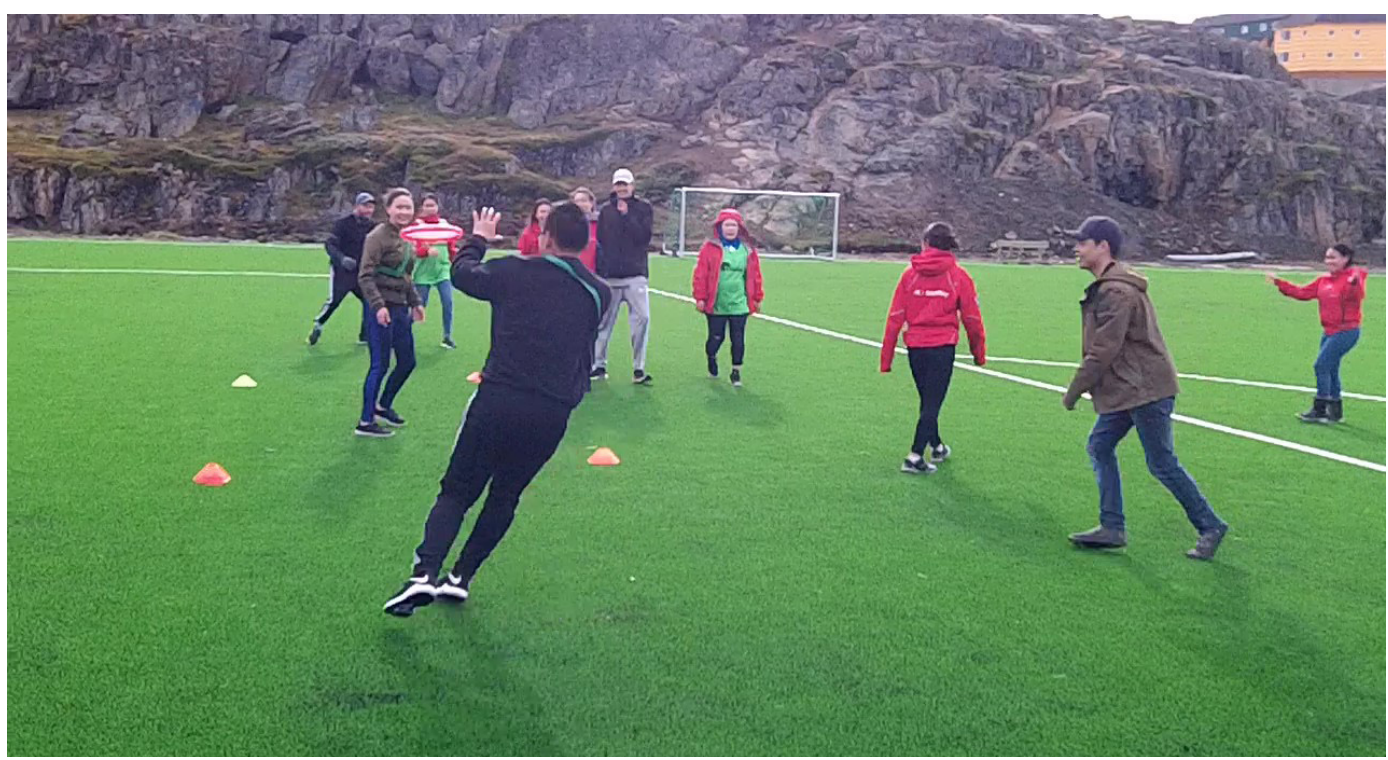




\section{REFERENCER}

Boolsen, M. W. (2016). Knudsen, R. J. (2016). Perspectives on skills: an anthology on informally acquired skills in Greenland. Denmark: University of Copenhagen.

Braun, V., Clarke, V., \& Weate, P. (2016). Using thematic analysis in sport and exercise research. In A. C. S. Brett Smith (Ed.), Routhledge handbook of qualitative research in sport and exercise (Vol. 1, pp. 191-206). New York: Routledge.

Coghlan, D., \& Brannick, T. (2014). Doing action research in your own organization: version 4 Sage.

Duus, G., Husted, M., Kildedal, K., Laursen, E., \& Tofteng, D. (2012). Aktionsforskning. Samfundslitteratur.

Hein, H. H. (2013). Primadonnaledelse: Når arbejdet er et kald. Gyldendal A/S.

Fullan, M., Hill, P., \& Crevola, C. (2006). Breakthrough. Thousand Oaks, CA: Corwin Press.

Goodyear, V. A., \& Casey, A. (2015). Innovation with change: Developing a community of practice to help teachers move beyond the 'honeymoon'of pedagogical renovation. Physical Education and Sport Pedagogy, 20(2), 186-203. https://doi.org/10.1080/1740898 9.2013 .817012

Hargreaves, A. (2009). A decade of educational change and a defining moment of opportunity-an introduction. Journal of Educational Change, 10(2-3), 89-10o. https://doi. org/10.1007/s10833-009-9103-4

Heikkinen, H. L., Huttunen, R., \& Syrjälä, L. (2007). Action research as narrative: five principles for validation. Educational Action Research, 15(1), 5-19. https://doi. org/10.1080/09650790601150709

KTI. (2017). GUX_ipaper. In KTI (Ed.). www.kti.gl, 14/11/2017.

Koskinen, I., Zimmerman, J., Binder, T., Redstrom, J., \& Wensveen, S. (2011). Design research through practice: From the lab, field, and showroom. Elsevier.

Kvale, S. (2009). Interview - Introduktion til et håndværk: Hans Reizels Forlag.

Qvortrup, L., \& LSP, A. U. (2015). Team'et som professionelt læringsfællesskab.

Sparkes, A. (2002). Telling tales in sport and physical activity: A qualitative journey: Human Kinetics Publishers.

Turner, J. C., Christensen, A., Kackar-Cam, H. Z., Fulmer, S. M., \& Trucano, M. (2018). The Development of Professional Learning Communities and Their Teacher Leaders: An Activity Systems Analysis. Journal of the Learning Sciences, 27(1), 49-88. doi:10.1080/ 10508406.2017.1381962

Vangrieken, K., Meredith, C., Packer, T., \& Kyndt, E. (2017). Teacher communities as a context for professional development: A systematic review. Teaching and Teacher Education, 61, 47-59. doi:https://doi.org/10.1016/j.tate.2016.10.001 
Ovens, A., Dyson, B., \& Smith, W. (2012). Implementing the Cooperative Learning model in physical education: The experience of New Zealand teachers. In Cooperative Learning in Physical Education (pp. 31-42). Routledge.

Spradley, J. P. (1980). Participant Observation. Belmont, C, United States: Cengage Learnin INC.

Wenger, E. (1999). Communities of practice: Learning, meaning, and identity: Cambridge university press.

Wenger, E., McDermott, R. A., \& Snyder, W. (2002). Cultivating communities of practice: A guide to managing knowledge: Harvard Business Press.

Fotos: Nic Ejsted (side 105) og Aqqalunnguaq Heilmann (side 110, 115 og 126).

\section{RESUMÉ}

I gymnasieskolen opleves i idrætsundervisning, som i andre fag, kulturelle udfordringer med gymnasiefremmede elever. Artiklen kobler sig til disse problematikker i det grønlandske gymnasium ved at analysere idrætslærernes arbejde med at skabe en udviklende kultur. Aktionsforskningen anvendt i projektet udfoldede sig på gymnasieskolen i Sisimiut i Vestgrønland, hvor 1.G elever og 4 lærere deltog som medforskere. Arbejdet med at skabe ny praksis førte til et PLF (Professionelt LæringsFællesskab). Fundene viste, at projektets rammer i form af kontekst, præmisser og processen indvirker på opnåede resultater, og at vedholdenhed, handletvang i forhold til afprøvning af konkret undervisning fremmer beslutningstagen og fører til nye indsigter.

\section{SUMMARY}

In PE, as in other subjects in high school, cultural challenges are experienced with students. This paper related to a Greenlandic high school, in which we analyses the work of PE teachers creating a developmental culture. The action research used in the project unfolded at the Sisimiut high school in West Greenland. 1.G students and four teachers participated as co-researchers. The work of creating new teaching practices led to a Professional Learning Community. The project's context, premises, and the process affect the results achieved, and forced action in testing concrete teaching promotes decision-making and leads to new insights. 
LARS ELBÆK er lektor ved Institut for Idræt og Biomekanik, Syddansk Universitet og er en del af forskningsenheden Learning \& Talent in Sport. Han har arbejdet med social innovation inden for undervisning siden 1997, hvor han løbende har udviklet og implementeret problembaseret læring (PBL) i idrætsuddannelser. Han har arbejdet med interaktionsdesign og brug af IT i idræt og bevægelse. Han har fostret ideen bag uddannelsesretningen Idræt, Innovation og Entreprenørskab og har udviklet og er underviser på kandidatkurserne Idræt og Læring samt Idræt og Design.

NICOLAI NIELSEN er gymnasielærer ved GUX Sisimiut og har været ansat siden 2013, hvor han færdiggjorde sin bachelor i idræt og sundhed. I årene som lærer ved GUX Sisimiut har Nicolai primært undervist i idræt og friluftsliv, men har også arbejdet med udvekslingsprojekter imellem andre nordiske gymnasieskoler og udvikling af GUX Sisimiuts mentorordning. Fra 2014-2018 har Nicolai ved siden af sit job som gymnasielærer gennemført kandidatuddannelse i Idræt og Sundhed ved Syddansk Universitet. I 2019 færdiggjorde han sin pædagogikumuddannelse.

KRISTIAN PEDERSEN er uddannet cand.scient. fra Syddansk Universitet i 2012 med hovedfag i idræt og sidefag i fysik. Til dagligt underviser Kristian i fysik, idræt og science ved GUX Sisimiut, Grønland. Udover virket som gymnasielærer er Kristian ansat som fagkonsulent for de naturvidenskabelige fag i Grønland. Han har desuden fire års undervisningserfaring fra den danske gymnasieskole samt undervisningserfaring fra Institut for Idræt og Biomekanik, Syddansk Universitetet samt idrætshøjskoleverdenen.

ANNE HOUMØLLER dimitterede i 2016 som cand. scient. fra Syddansk Universitet med hovefag i idræt og sidefag i biologi. Siden 2016 har hun undervist på GUX Sisimiut, Grønland, i fagene idræt, science og biologi. I 2018 færdiggjorde hun sin pædagogikumuddannelse. Anne har derudover undervisningserfaring fra Institut for Idræt og Biomekanik ved Syddansk Universitet og DGI. 